\title{
Clinical Usefulness of Combined Cardiac Marker Testing with a Point-of-Care Device at the Emergency Department
}

Misuk Ji ${ }^{1}$, Hee-Won Moon ${ }^{2}$, Seungman Park $^{3}$, Mina Hur ${ }^{2}$, and Yeo-Min Yun ${ }^{2}$

${ }^{1}$ Department of Laboratory Medicine, Veterans Health Service Medical Center; ${ }^{2}$ Department of Laboratory Medicine, Konkuk University School of Medicine, Seoul; ${ }^{3}$ Green Cross Laboratories, Yongin, Korea

\section{Corresponding author:} Yeo-Min Yun

Department of Laboratory Medicine, Konkuk University Medical Center, Konkuk University School of Medicine, 120-1 Neungdong-ro, Gwangjingu, Seoul 05030, Korea Tel: +82-2-2030-5582

Fax: +82-2-2030-5587

E-mail: ymyun@kuh.ac.kr

\begin{abstract}
Background: B-type natriuretic peptide (BNP) levels are elevated in various conditions unrelated to heart failure, such as acute coronary syndrome, and cardiac troponin ( $\mathrm{cTn}$ ) levels may also be elevated in several non-ischemic conditions. This study aimed to evaluate the clinical usefulness of combined cardiac marker testing (BNP and cTnI) with point-ofcare devices in patients who presented to the emergency department (ED).

Methods: Two thousand six hundred and seventy-four consecutive patients who visited the ED from March to August 2013 were included in this study. Cardiac marker testing was performed using the Triage Cardio3 panel (Alere, USA). Electronic medical records were collected on August 2014.

Results: We found that $22.2 \%$ patients had elevated BNP and/or cTnI (12.8\% with only elevated BNP, $4.4 \%$ with only elevated cTnI, and 5.0\% with both elevations). Patients with elevations in both marker levels showed significantly higher admission rate $(78.5 \%$ vs. $62.7 \%$, $P=0.006$ ) and longer length of hospital stay (11 vs. 6 days, $P=0.001$ ) than those with only elevated cTnI. Patients with elevations in both marker levels also showed higher admission rate $(78.5 \%$ vs. $67.3 \%, P=0.016)$ and higher BNP levels ( 430 vs. $194 \mathrm{pg} / \mathrm{mL}, P<0.001)$ than those with only elevated BNP.

Conclusions: Concurrent elevation of BNP and cTnI may be associated with inferior clinical outcome and combined testing of $\mathrm{cTnI}$ and BNP levels with high sensitivity would provide important information for assisting management decisions at the ED.
\end{abstract}

(J Lab Med Qual Assur 2017;39:83-89)

Key Words: Troponin I, B-type natriuretic peptide, Emergency department

\section{INTRODUCTION}

B-type natriuretic peptide (BNP) is synthesized in the ventricular myocardium and released into circulation in response to ventricular dilatation and pressure overload [1]. In addition to its roles in the diagnosis, exclusion, and risk stratification of congestive heart failure, BNP can also provide prognostic information in patients with acute coronary syndrome (ACS) [1-3]. Higher BNP levels predict higher risk for death due to post-myocardial infarction and heart failure independent of the status of troponin [1]. Cardiac troponins (cTn) are both sensitive and specific markers of cardiac myonecrosis, and higher levels predict worse outcomes [4-6]. cTn is also elevated in many non-ischemic conditions, including acute and chronic heart failure, myocarditis, critical illness, and sepsis [7]. Elevated cTn levels correlate with adverse prognosis in patients without ACS. cTn values above the 99th 
percentile of the upper reference limit are suggested as prognostic markers in patients with acute decompensated heart failure [8] or other heart failure [6].

Accordingly, the implementation of multiple biomarker approach, including both cTn and BNP, might be considered in patients with possible ACS at the emergency department (ED). Several point-of-care (POC) devices for cardiac marker testing are currently in use at various sites, including the ED, due to rapid turnaround time and users' convenience $[9,10]$. This study aimed to evaluate the clinical usefulness of combined cardiac marker testing with a POC device in unselected patients who present to the ED.

\section{MATERIALS AND METHODS}

\section{Study Population}

From March to August 2013, adult patients (over 18 years-old) who visited the ED of the Konkuk University Medical Center and received simultaneous BNP and cTnI testing with a POC device were included in this study. A total of 2,674 patients were enrolled, and they had symptoms or signs of possible ACS or risk factors. The mean age of all patients was 58.9 years. The institution is a tertiary care community hospital located in Seoul with approximately 50,000 annual ED visits. This study was approved by the institutional review board of the Konkuk University Medical Center (approval no. KUH1200035).

\section{1) Cardiac marker testing}

BNP and cTnI were measured by the Triage Cardio3 panel (Alere, San Diego, CA, USA) with a Triage meter device. Cutoff value of BNP was $100 \mathrm{pg} / \mathrm{mL}[11,12]$. For cTnI, the 99th percentile value was $0.02 \mathrm{ng} / \mathrm{mL}$ and the cutoff for determination of clinical sensitivity was $0.4 \mathrm{ng} /$ $\mathrm{mL}$ according to the manufacturer's guidelines $[11,12]$. cTnI values $\geq 0.03 \mathrm{ng} / \mathrm{mL}$ were considered as elevated cTnI, whereas those between 0.03 and $0.4 \mathrm{ng} / \mathrm{mL}$ were interpreted as low-level positive, which is indicative of marginally increased cTnI levels [13]. cTnI values above $0.4 \mathrm{ng} / \mathrm{mL}$ were interpreted as overtly positive. The cTnI results were divided into 3 groups (negative, low-level positive, and overtly positive). Creatine kinase-myocardial band results were not included in this study. For cTnI, total coefficient of variation at the 99th percentile was $17.0 \%$, and hence, this assay was clinically usable according to the Apple scorecard $[14,15]$.

\section{2) Data collection}

Patients' electronic medical records including diagnosis at the time of admission, admission rate, length of stay, rate of readmission within 3 months, and mortality rates were retrospectively collected on August 2014. Patients showing any positivity for cTnI or BNP were reviewed.

\section{3) Statistical analysis}

The IBM SPSS Software ver. 19.0 (IBM Corp., Armonk, NY, USA) was used for statistical analysis. The independent $t$-test or the Mann-Whitney U-test was used to compare continuous variables, and the chi-square test was used to compare categorical variables. $P$-values less than 0.05 were considered statistically significant.

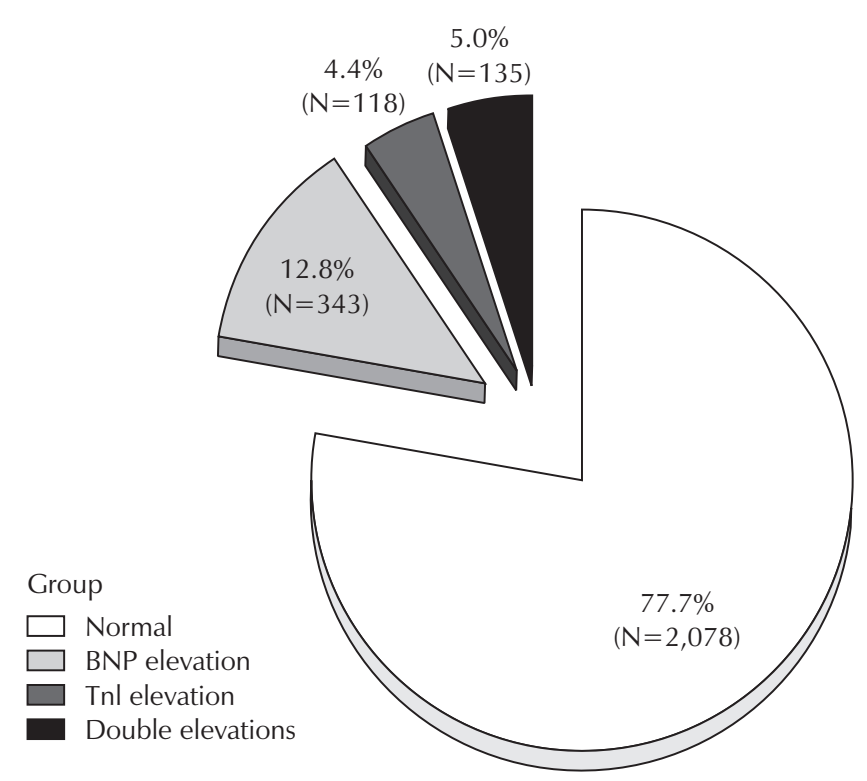

Fig. 1. Distribution of patients based on the positivity for two cardiac markers. Five hundred and ninety-six patients (22.3\%) had elevated BNP and/or cTnI concentrations. The 99th percentile of cardiac troponin I is $0.02 \mathrm{ng} / \mathrm{mL}$, and hence, values $\geq 0.03 \mathrm{ng} / \mathrm{mL}$ were considered to be positive. The cutoff for BNP is $100 \mathrm{pg} / \mathrm{mL}$. Abbreviations: BNP, B-type natriuretic peptide; cTnI, cardiac troponin I. 


\section{RESULTS}

\section{Distribution of the Emergency Department Patients}

The study participants were divided into 4 categories according to the results of cardiac marker testing: BNP elevation only (343, 12.8\%), cTnI elevation only (118, $4.4 \%)$, both elevations $(135,5.0 \%)$, and both negative $(2,078,77.7 \%$ ) (Fig. 1). In total, $22.3 \%$ patients had elevated BNP and/or cTnI. The mean age of these patients was significantly higher than those of subjects who tested negative for both markers $(70.7 \pm 14.2$ versus $54.9 \pm 18.4$ years, $P<0.001$ ).

\section{1) Comparison of double marker elevation with single marker elevation}

Patients with elevations in both marker levels revealed higher admission rate after the $\mathrm{ED}$ visit (78.5\% versus $62.7 \%, P=0.006$ ) and longer length of hospital stay after admission (median [interquartile range], 11 [5-19] versus 6 [3-13] days; $P=0.001$ ) than those with only cTnI elevation. The length of hospital stay was further calculated after excluding patients with cerebral infarction, cerebral hemorrhage, gastrointestinal bleeding, or major fractures. The median length of hospital stay was 11 (516) and 5.5 (4-11.8) days for patients with elevations in both markers and only cTnI elevation, respectively. The number of excluded patients was 13 for the BNP only elevation group, 12 for the cTnI only elevation group, and 11 for the double elevation group. In addition, patients with elevations in both markers showed higher admission rate after the $\mathrm{ED}$ visit (78.5\% versus $67.3 \%, P=0.016$ ), higher BNP levels (430 [228-727] versus 194 [140-322] $\mathrm{pg} / \mathrm{mL}, P<0.001)$, and shorter length of ED stay (228 [151-345] versus 263 [185-345] minutes, $P=0.026$ ) than those with only BNP elevation. Other variables were insignificant (Table 1 and Fig. 2).

The diagnosis at the time of admission was categorized into organ-based major groups. For patients with double elevations $(\mathrm{N}=105)$, cardiovascular disease $(\mathrm{N}=43$, $41.0 \%$ ) was most common, followed by respiratory disease $(\mathrm{N}=18,17.1 \%)$ and gastrointestinal disease $(\mathrm{N}=11$, $10.5 \%)$. The most common diagnosis of a single disease was heart failure $(\mathrm{N}=16)$, followed by ACS $(\mathrm{N}=13)$, and pneumonia $(\mathrm{N}=12)$. For patients with only c $\mathrm{TnI}$ elevation $(\mathrm{N}=74)$, cardiovascular disease $(\mathrm{N}=30,40.5 \%)$ was the most common disease, followed by neurological $(\mathrm{N}=20$, $27.0 \%)$, respiratory $(\mathrm{N}=7,9.5 \%)$, and gastrointestinal diseases $(\mathrm{N}=7,9.5 \%)$. The most common diagnosis of a single disease was ACS $(\mathrm{N}=20)$, followed by cerebral infarction $(\mathrm{N}=6)$, and stable angina $(\mathrm{N}=5)$. For patients

Table 1. Clinical and laboratory characteristics in patients with cardiac troponin I and/or B-type natriuretic peptide elevation

\begin{tabular}{|c|c|c|c|c|c|}
\hline \multirow[t]{2}{*}{ Variable } & \multirow{2}{*}{$\begin{array}{c}\text { Patients with } \\
\text { double elevations } \\
(\mathrm{N}=135) \\
\mathrm{cTnI}(+) / \mathrm{BNP}(+)^{\star}\end{array}$} & \multicolumn{2}{|c|}{$\begin{array}{c}\text { Patients with only } \\
\text { cTnI elevation }(\mathrm{N}=118)\end{array}$} & \multicolumn{2}{|c|}{$\begin{array}{c}\text { Patients with only } \\
\text { BNP elevation }(\mathrm{N}=343)\end{array}$} \\
\hline & & $\operatorname{cTnI}(+) / \mathrm{BNP}(-)^{*}$ & $P$-value ${ }^{\dagger}$ & $\operatorname{cTnI}(-) / \mathrm{BNP}(+)^{*}$ & $P$-value ${ }^{\dagger}$ \\
\hline Age (yr) & $74.2 \pm 11.2$ & $61.9 \pm 16.8$ & $<0.001$ & $72.4 \pm 13.1$ & 0.145 \\
\hline Length of ED stay (min) & $228(151-345)$ & $200(103-326)$ & 0.112 & $263(185-345)$ & 0.026 \\
\hline Readmission rate within 3 months of discharge (\%) & $17.9(19 / 106)$ & $10.8(8 / 74)$ & 0.188 & $16.5(38 / 231)$ & 0.737 \\
\hline Mortality rate within 1 year $(\%)^{\ddagger}$ & $17.0(19 / 112)$ & $17.9(14 / 78)$ & 0.860 & $12.7(31 / 245)$ & 0.276 \\
\hline cTnI (ng/mL, half-life about 2 hr) & $0.07(0.04-0.18)$ & $0.05(0.03-0.19)$ & 0.429 & $0.01(0.01-0.01)$ & - \\
\hline BNP (pg/mL, half-life 20 min) & $430(228-727)$ & $23(9-46)$ & - & $194(140-322)$ & $<0.001$ \\
\hline
\end{tabular}

Values are presented as mean $\pm \mathrm{SD}$, median (interquartile range), or percentage (number of patients/total patients included in the analysis). Abbreviations: cTnI, cardiac troponin I; BNP, B-type natriuretic peptide; ED, emergency department.

${ }^{*}$ The 99th percentile of cardiac troponin I is $0.02 \mathrm{ng} / \mathrm{mL}$. Thus, values $\geq 0.03 \mathrm{ng} / \mathrm{mL}$ were considered positive. The cutoff for BNP is 100 $\mathrm{pg} / \mathrm{mL} .{ }^{\dagger} \mathrm{P}$-values were calculated in comparison with the patients with both cardiac marker elevations. ${ }^{\ddagger}$ Mortality rate was calculated after excluding the patients with follow-up loss. 


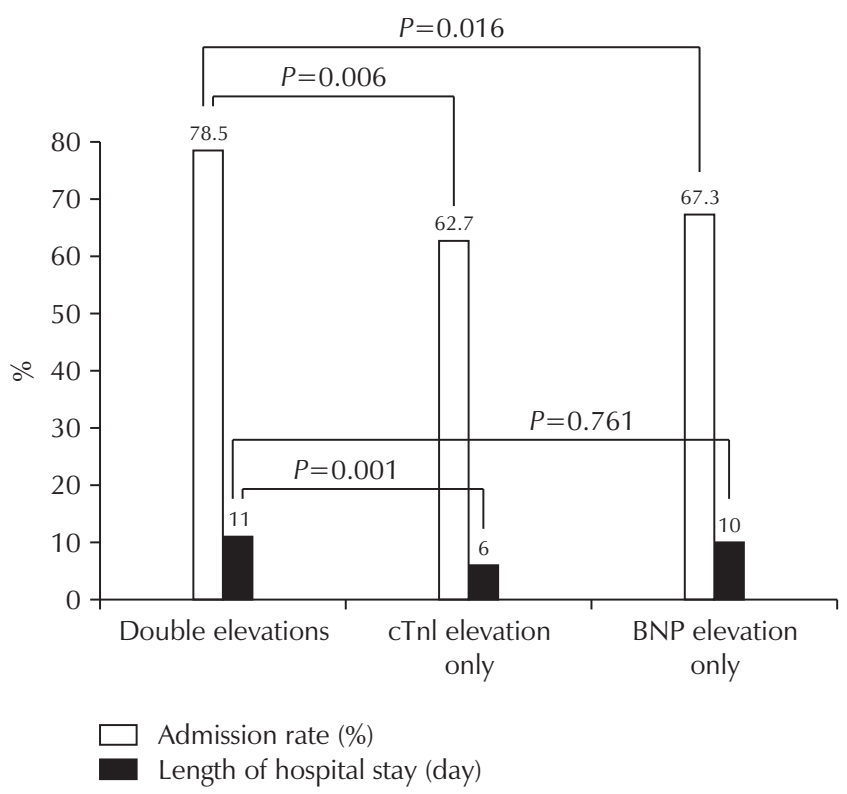

Fig. 2. Admission rate and length of hospital stay after admission of each group based on the combinatin of cTnI and BNP levels. Length of hospital stay presented as median value and interquartile ranges are as follows: 5-19, 3-13, and 5-20 days for both positive, cTnI positive only, and BNP positive only groups, respectively. Abbreviations: cTnI, cardiac troponin I; BNP, B-type natriuretic peptide.

with only BNP elevation ( $\mathrm{N}=231)$, cardiovascular disease ( $\mathrm{N}=48,20.8 \%$ ) was the most common affliction, followed by gastrointestinal $(\mathrm{N}=46,19.9 \%)$, respiratory $(\mathrm{N}=42$, $18.2 \%)$, neurological $(\mathrm{N}=39,16.9 \%)$, and renal diseases $(\mathrm{N}=27,11.7 \%)$. The most common diagnosis as a single disease was pneumonia $(\mathrm{N}=29)$, followed by heart failure $(\mathrm{N}=19)$, cerebral infarction $(\mathrm{N}=19)$, chronic kidney disease $(\mathrm{N}=14)$, and cholangitis $(\mathrm{N}=10)$.

\section{2) Patients with marginally increased cardiac troponin}

Among the 253 patients with elevated cTnI (sole cTnI elevation and concurrent BNP elevations together), 212 patients $(83.8 \%)$ showed low-level positivity. In this subgroup, patients with elevations in both markers were also hospitalized more at the ED (76.7\% versus $59.4 \%$, $P=0.010)$ and had longer length of hospital stay after admission (10 [5-21] versus 6 [4-15] days, $P=0.019)$ than those with only cTnI elevation.

\section{DISCUSSION}

In this study, we determined whether simultaneous measurements of BNP and cTnI were relevant at the ED where time is critical and enough data about patients is unavailable in many cases. We found that the hospital course of the patients with elevations in both biomarkers appeared to be different compared to those with elevations in levels of only cTnI or BNP. The multiple marker approach can provide additional information regarding the simultaneous elevation of the marker levels, other than assisting in the diagnosis/exclusion of ACS in cases of possible heart failure.

The ED physician might have considered the clinical status of patients positive for both the markers to be more serious, which might have increased the admission rate (Table 1 and Fig. 2). The length of hospital stay after admission was longer in patients with double elevations compared to those with cTnI only elevation, but similar to those with BNP only elevation. This might be related to chronicity of disease or relatively older mean age ( $>70$ years) in patients with BNP elevation. Among patients with cTnI elevation, certain findings such as higher admission rate and longer length of hospital stay were still observed when the patients with low-level positive cTnI (0.03-0.40 ng/mL) were only included in the analysis. This level of elevation can be observed in various clinical situations, and the patients are relatively heterogeneous in terms of their afflictions compared to those with overtly positive cTnI levels.

POC testing of cTnI and BNP may assist the ED physicians in prompt triage, accurate diagnosis, and management of patients due to rapid delivery of the results within 15-20 minutes with comparable sensitivity and specificity $[9,10,16]$. POC testing of cTn1 has also resulted in a substantial lowering of charges per patient admission in a metropolitan medical center of the USA, although in a small number of patient $[10,17]$. In this study, about one of five patients $(22.3 \%, 596 / 2,674)$ who visited the $\mathrm{ED}$ of the university hospital and underwent POC testing showed positive cTnI and/or BNP result. Our patients might represent a mixed population with 
variable clinical situations, although each hospital may be identified by specific patient characteristics. The positive rates for cTn or BNP differ according to the patient population and cutoff used $[13,16]$. Troponin (cutoffs 1.0 and $0.1 \mu \mathrm{g} / \mathrm{L}$ for $c \operatorname{TnI}$ and $c \operatorname{TnT}$, respectively) was positive in $6.2 \%$ patients with acute decompensated heart failure, and BNP (cutoff $80 \mathrm{pg} / \mathrm{mL}$ ) was positive in 10.6\% patients with ST-segment elevation myocardial infarction in previous studies $[18,19]$.

This study has several limitations. First, we did not review the medical records of the patients who were negative for both the markers in detail. Therefore, the admission rates of the cTnI-negative and the BNPnegative group could not be calculated. In addition, other factors affecting admission rate and hospitalization period were not assessed. Second, this study was retrospective in design. Third, positive BNP results could be due to decreased renal function such as chronic kidney disease. Fourth, we could not compare the results of the central laboratory with those of $\mathrm{POC}$ testing.

In conclusion, we observed that patients with concurrent elevations of BNP and cTnI may be associated with inferior clinical outcome. Combined and sensitive testing of cTnI and BNP would provide additional information for patients with suspected ACS and aid in the identification of heart failure. In addition, it would assist in excluding ACS in patients with suspected heart failure, which can be helpful for management decisions.

\section{REFERENCES}

1. De Lemos JA, Morrow DA, Bentley JH, Omland T, Sabatine MS, McCabe $\mathrm{CH}$, et al. The prognostic value of B-type natriuretic peptide in patients with acute coronary syndromes. N Engl J Med 2001;345:1014-21.

2. Morrow DA, Cannon CP, Jesse RL, Newby LK, Ravkilde J, Storrow AB, et al. National Academy of Clinical Biochemistry Laboratory Medicine practice guidelines: clinical characteristics and utilization of biochemical markers in acute coronary syndromes. Circulation 2007;115:e356-75.

3. Christenson E, Christenson RH. The role of cardiac biomarkers in the diagnosis and management of patients presenting with suspected acute coronary syndrome. Ann Lab Med 2013;33:309-18.

4. Myint PK, Kwok CS, Bachmann MO, Stirling S, Shepstone L, Zaman MJ. Prognostic value of troponins in acute coronary syndrome depends upon patient age. Heart 2014;100:1583-90.

5. Antman EM, Tanasijevic MJ, Thompson B, Schactman M, McCabe CH, Cannon CP, et al. Cardiac-specific troponin I levels to predict the risk of mortality in patients with acute coronary syndromes. N Engl J Med 1996;335:1342-9.

6. Newby LK, Jesse RL, Babb JD, Christenson RH, De Fer TM, Diamond GA, et al. ACCF 2012 expert consensus document on practical clinical considerations in the interpretation of troponin elevations: a report of the American College of Cardiology Foundation task force on Clinical Expert Consensus Documents. J Am Coll Cardiol 2012;60:2427-63.

7. Mahajan VS, Jarolim P. How to interpret elevated cardiac troponin levels. Circulation 2011;124:2350-4.

8. Felker GM, Hasselblad V, Tang WH, Hernandez AF, Armstrong PW, Fonarow GC, et al. Troponin I in acute decompensated heart failure: insights from the ASCENDHF study. Eur J Heart Fail 2012;14:1257-64.

9. Apple FS, Ler R, Murakami MM. Determination of 19 cardiac troponin I and T assay 99th percentile values from a common presumably healthy population. Clin Chem 2012;58:1574-81.

10. Di Somma S, Zampini G, Vetrone F, Soto-Ruiz KM, Magrini L, Cardelli P, et al. Opinion paper on utility of point-of-care biomarkers in the emergency department pathways decision making. Clin Chem Lab Med 2014;52:1401-7.

11. Alere. Triage Cardiac Panel Package. San Diego (CA): Alere, 2004.

12. Alere. Triage Cardio3 Panel Package. San Diego (CA): Alere, 2010.

13. Hubbard BL, Newton CR, Carter PM, Fowler JJ, Schaldenbrand J, Singal B, et al. The inability of B-type natriuretic protein to predict short-term risk of death or myocardial infarction in non-heart-failure patients with marginally increased troponin levels. Ann Emerg Med 


\section{Journal of LABORATORY MEDICINE and QUALITY ASSURANCE}

Misuk Ji et al $\bullet$ Combined Cardiac Markers in the ED

2010;56:472-80

14. International Federation of Clinical Chemistry and Laboratory Medicine. Analytical characteristics of commercial cardiac troponin I and T assays declared by the manufacturer. http://www.ifcc.org/media/276664/ IFCC\%20Troponin\%20Tables\%20ug_L_DRAFT\%20 Update\%20NOVEMBER\%202014.pdf (Accessed March 17, 2016).

15. Apple FS. A new season for cardiac troponin assays: it's time to keep a scorecard. Clin Chem 2009;55:1303-6.

16. Nayer J, Aggarwal P, Galwankar S. Utility of point-of-care testing of natriuretic peptides (brain natriuretic peptide and n-terminal pro-brain natriuretic peptide) in the emergency department. Int J Crit Illn Inj Sci 2014;4:209-
15.

17. Apple FS, Chung AY, Kogut ME, Bubany S, Murakami MM. Decreased patient charges following implementation of point-of-care cardiac troponin monitoring in acute coronary syndrome patients in a community hospital cardiology unit. Clin Chim Acta 2006;370:191-5.

18. Peacock WF 4th, De Marco T, Fonarow GC, Diercks D, Wynne J, Apple FS, et al. Cardiac troponin and outcome in acute heart failure. N Engl J Med 2008;358:2117-26.

19. Mega JL, Morrow DA, De Lemos JA, Sabatine MS, Murphy SA, Rifai N, et al. B-type natriuretic peptide at presentation and prognosis in patients with ST-segment elevation myocardial infarction: an ENTIRE-TIMI-23 substudy. J Am Coll Cardiol 2004;44:335-9. 


\section{응급실 내원 환자에서 심장표지자 현장검사 동시 시행의 유용성 지미숙 ${ }^{1}$ 문희원 ${ }^{2} \cdot$ 박승만 $^{3} \bullet$ 허미나 $^{2} \cdot$ 윤여민 $^{2}$ \\ 중앙보훈병원 진단검사의학과, ${ }^{2}$ 건국대학교 의학전문대학원 진단검사의학교실, ${ }^{3}$ 녹십자의료재단}

배경: B형나트륨이뇨펩타이드(B-type natriuretic peptid, BNP)는 심부전 관련 표지자이지만 급성 관동맥증후군에서도 증가할 수 있으며, 심장트로포닌(cardiac troponin, cTn)도 많은 비허혈성 질환 에서 증가할 수 있다. 이 연구는 건국대학교병원 응급실로 내원한 환자에서 현장검사로 동시에 검사 한 BNP와 cTnl의 임상적 유용성을 평가하고자 하였다.

방법: 2013년 3월부터 8월까지 2,674명의 환자가 포함되었다. 심장표지자검사는 Triage Cardio3 Panel (Alere, USA)로 시행하였다. 의무기록 검토는 2014년 8월에 시행하였다.

결과: 전체 환자 중 22.3\%에서 BNP 또는 cTnl가 증가되어 있었으며, BNP만 증가되어 있는 경우가 $12.8 \%, \mathrm{cTn}$ l만 증가되어 있는 경우가 $4.4 \%$, 둘 다 증가되어 있는 경우가 $5.0 \%$ 였다. 두 표지자 모두 증가되어 있었던 환자들은 cTnl만 증가된 환자와 비교했을 때 유의하게 높은 입원율과 입원 후 더 긴 재원기간을 나타내었고, BNP만 증가된 환자와 비교했을 때 유의하게 높은 입원율과 높은 BNP 값을 나타내었다.

결론: cTnl 및 BNP 동시 상승은 응급실을 방문한 환자에서 상대적으로 불량한 임상상과 관련이 있었 으며, 동시에 두 표지자를 검사하는 것은 치료방침 결정에 중요한 역할을 할 수 있다고 생각된다.

(J Lab Med Qual Assur 2017;39:83-89)

\section{교신저자: 윤여민}

우)05030 서울시 광진구 능동로 120-1, 건국대학교 의학전문대학원 진단검사의학과

Tel: 02)2030-5582, Fax: 02)2030-5587, E-mail: ymyun@kuh.ac.kr 